ORIGINAL ARTICLE

Arslan Kağan Arslan ${ }^{1}$

Hatice Tolunay ${ }^{2}$

${ }^{1}$ Yenimahalle Training and

Research Hospital,

Department of Orthopaedics

and Traumatology, Ankara,

Turkey

${ }^{2}$ Yenimahalle Training and

Research Hospital,

Department of Cardiology,

Ankara, Turkey

Corresponding Author:

Arslan Kagan Arslan

Yenimahalle Training and

Research Hospital, Department

of Orthopaedics and

Traumatology, Ankara, Turkey

Tel: +905325663217

E-mail:

arslankagan@gmail.com

Received: 12.03.2019

Acceptance: 10.05.2019

DOI: 10.18521/ktd.538977

Konuralp Medical Journal e-ISSN1309-3878

konuralptipdergi@duzce.edu.tr konuralptipdergisi@gmail.com www.konuralptipdergi.duzce.edu.tr

\section{Analysis of Bone Mineral Density and Hip Fracture in Geriatric Patients with Heart Failure \\ ABSTRACT}

Objective: Osteoporosis, identified by low Bone Mineral Density (BMD), is a progressive disease affecting especially older adults. Hip fracture is the important result of osteoporosis. Heart failure and osteoporosis are two common chronic conditions that are critical in healthcare of older adults. This study is aimed at evaluating bone mineral density and hip fractures in geriatric aged patients with heart failure.

Methods: We retrospectively analyzed 157 geriatric patients with heart failure and 155 geriatric control subjects without any cardiovascular disease and risk factors. The results of transthoracic echocardiography, biochemical analysis and bone mineral densitometry results (DEXA) were evaluated from patient file data. Medical records of clinics provided the osteoporotic fracture history and operation for fracture, list of current and prior use of medications.

Results: Among the 157 patients, 45 (29\%) had normal BMD, 14 (9\%) had osteopenia, and $98(62 \%)$ had osteoporosis. In 155 control subjects, 68 (44\%) had normal BMD, 12 $(8 \%)$ had osteopenia, and $75(46 \%)$ had osteoporosis $(\mathrm{P}=0.019)$. Sixteen subjects $(10.2 \%)$ in heart failure group and 6 subjects $(3.9 \%)$ in controls had hip fracture $(\mathrm{p}=0.029)$. Level of 25 -hydroxy vitamin D was significantly lower in heart failure than in controls $(\mathrm{p}<0.001)$.

Conclusions: Patients with heart failure have a lower bone mineral density, low vitamin D level and an increased rate of hip fractures. These findings can be explained by shared risk factors and pathogenetic mechanisms. Further prospective studies should be performed for evaluating the role of heart failure in osteoporotic hip fractures.

Keywords: Vitamin D, Hip Fracture, Heart Failure, Bone Mineral Density, Osteoporosis.

\section{Kalp Yetersizliği Olan Geriatrik Hastalarda Kemik Mineral Dansitometri ve Kalça Kırıklarının Değerlendirilmesi \\ ÖZET}

Amaç: Osteroporoz özellikle yaşlı hastaları etkileyen, düşük kemik mineral dansitometri (KMD) ile tanımlanan ilerleyici bir hastalıktır. Kalça kırı̆̆ osteoporozun önemli bir sonucudur. Osteoporoz ve kalp yetersizliği, yaşlı hastalarda giderek önem kazanan iki önemli kronik sağlık sorunudur. Bu çalışmada kalp yetersizliği olan geriatrik yaş grubunda kemik mineral dansitometri sonuçları ve kalça kırıklarının değerlendirilmesi amaçlanmıştır. Gereç ve Yöntem: 65 yaş ve üzeri kalp yetersizliği tanısı almış 157 hasta ve kontrol grubu olarak kardiovasküler risk faktörü ve hastalığı olmayan 155 hasta retrospektif olarak değerlendirildi. Hastaların transtorasik ekokardiyografi sonuçları, biyokimyasal analizleri ve kemik mineral dansitometri sonuçları (DEXA) hasta dosya verilerinden incelendi. Osteoporotik kırık ve kırık için operasyon öyküsü, kullanmakta olduğu ve önceki kullandığı ilaç listesi, diğer takipli olduğu merkezlerin tıbbi kayıtlarından elde edildi

Bulgular: Kalp yetersizliği olan 157 hastanın, 45'inde (\%29) normal KMD, 14'ünde (\%9) osteopeni ve 98'inde (\%62) osteoporoz vardi. Kontrol grubunda 155 hastanin 68'inde $(\% 44)$ normal KMD, 12 'sinde $(\% 8)$ osteopeni ve 75 'inde $(\% 46)$ osteoporoz saptand $(\mathrm{p}=$ $0,019)$. Kalp yetersizliği grubunda $16(\% 10,2)$ ve kontrollerde 6 olguda $(\% 3,9)$ kalça kırı̆g 1 öyküsü vardı $(\mathrm{p}=0,029)$. 25-hidroksi vitamin $\mathrm{D}$ seviyesi kontrol grubuna göre kalp yetersizliği olan grupta istatistiksel olarak düşük bulundu $(\mathrm{p}<0,001)$.

Sonuç: Kalp yetersizliği olan hastalarda daha düşük kemik mineral yoğunluğu, düşük D vitamini düzeyi ile birlikte kalça kırı̆ğ oranında artış olup, bu bulgular mevcut risk faktörleri ve patogenetik mekanizmalar ile açıklanabilir. Osteoporotik kalça kırıklarında, kalp yetersizliğinin rolünü değerlendirmek için prospektif ileri çalışmalara ihtiyaç vardır.

Anahtar Kelimeler: Vitamin D, Kalça Kırığı, Kalp Yetersizliği, Kemik Mineral Dansitometri, Osteoporoz. 


\section{INTRODUCTION}

Aging is associated with morphological and functional changes in human tissue. A dramatic increase in older adults causes an increase in multiple medical and surgical conditions. In geriatric population there are many diseases which have a close relationship with each other. Heart failure and osteoporosis are two common chronic conditions that are critical in healthcare of older adults. In frail older adults, incidence of both HF and osteoporosis are frequent (1-3). It is crucial to assess the interaction of these common conditions in geriatric populations.

Osteoporosis defined by low Bone Mineral Density (BMD), is a progressive disease affecting especially older adults. In a study from our country, its prevalence in the geriatric age group was reported as $46.6 \%$ in men and $64.1 \%$ in women (4). The crucial concern about low BMD is the high risk of hip fractures. Surgical repair, extended hospital stay and rehabilitation therapy may be needed in the occurrence of a hip fracture. Hip fracture is also associated with increased risk of mortality (5).

Common risk factors influence both heart diseases and bone metabolism. Coexistence of these two conditions, osteoporosis and heart failure, in older adults may be affected by these risk factors. An independent correlation between osteoporosis and coronary artery disease was reported recently (6).

The aim of this study is to evaluate bone mineral density and hip fractures in geriatric aged patients with heart failure.

\section{MATERIAL AND METHODS}

Patients and their selection: Our study was approved by the local ethics committee. A retrospective analysis of 312 patients between August 2013 and January 2015 was performed. This cross-sectional study was conducted in Orthopedics and Cardiology outpatient clinics. The study included 157 geriatric patients with heart failure and 155 geriatric control subjects without any cardiovascular disease and risk factors. Exclusion criteria were alcoholism, malignancy, chronic renal disease, collagen vascular disease and infection.

Medical records of each clinic as well as case report forms provided by the patients were collected for information on patient demographics and clinical parameters, including any osteoporotic fracture history and operation for fracture, list of current and prior use of medications.

Clinical laboratory and echocardiography findings of the study population were evaluated. BMD values in patients with heart failure versus control subjects at each main skeletal site were evaluated too. After the data collection was completed, heart failure group and control group were compared for the patient demographic characteristics and the clinical parameters.

Transthoracic Echocardiography: All patients underwent a transthoracic echocardiographic examination (System three (GE Vingmed Ultrasound, Horten, Norway) cardiac ultrasound scanner and $3.5 \mathrm{MHz}$ transducers were used.

Left atrial and left ventricular dimensions were evaluated in the parasternal long axis view. By using $M$ mode echocardiography, left ventricular end diastolic and end systolic dimension were measured. In the parasternal long axis view aortic root diameter was taken. Teichholz equation was used to provide the left ventricular ejection fraction (LVEF)

Biochemical Analysis: An automatic analyzer (Konelab 60İ, Thermo Scientific, Filland) was used to enzymatically measure fasting serum total cholesterol, triglycerides, LDL-cholesterol, HDL-cholesterol, (Lot No: B302, Konelab), alanine aminotransferase (ALT) (Lot No: C239, Konelab), Gamma-glutamyltransferase (GGT) (Lot No: C331, Konelab), and aspartate aminotransferase (AST) (Lot No: C372, Konelab). Triglycerides (Lot No: C186, Konelab) and total cholesterol (Lot No: B540, Konelab) were evaluated with enzymatic colorimetric tests, HDL-C (Lot No: C136, Konelab) and low-density lipoprotein-cholesterol (Lot No: C435, Konelab) were evaluated with the homogeneous enzymatic colorimetric test. The alkaline picrate (Jaffe) method (Lot No: C092, Konelab) was used to measure the serum creatinine.

By using osteocalcin kit (Catalog No: LKON1) osteocalcin was measured with Immulite 1000 (Siemens Healthcare DiagnosticsIL, USA). Bone Alkaline Phosphatase level was calculated with Ostease IRMA kit (Immunotech, Beckman Coulter, Inc. Fullerton, CA, USA). Serum 25 hydroxyvitamin-D, calcitriol, and B-ALP levels were calculated with RIA. 1,25(OH)2-VIT.D3RIA-CT kit (Catalog No: KIP1921) (Biosource, Neville, Belgium) and 25OH-VIT.D3-RIA-CT kit (Catolog No: KIP1961) were used.

\section{BMD measurements: L2-L4} anteroposterior lumbar spine and a femoral neck bone DEXA study were applied to the patients. The radiology department performed the BMD studies. Results were named as T- and Z-scores. Below the mean BMD for sex-matched young controls $\mathrm{T}$ scores were described as numbers of standard 
deviations. The patients were stratified according to World Health Organization Study.

Group recommendation: In comparison to the control values, lumbar spine $\mathrm{T}$-scores were accepted as normal if $\mathrm{T}$-score was greater than -1 , osteopenic if the T-score was between -1 and -2.5 , and osteoporotic if the $\mathrm{T}$ score was less than or equal to -2.5 compared to the control values where appropriate (7). Below the mean BMD of sex and age matched controls $\mathrm{Z}$ scores were described as the number of standard deviations.

Statistical analysis: Statistical analyses were performed using the statistical package SPSS 10.0 for Windows. The Kolmogorov-Smirnov test was used for evaluating numeric variables of the study group met the assumption of normal distribution. Descriptive statistics of the numerical parametric variables were calculated as mean \pm standard deviation; non-parametric variables were calculated in the median (minimum-maximum); and categorical variables were expressed as a percentage $(\%)$. To compare categorical variables between groups, a Chi-square test was used. For the comparison of categorical variables between groups, an independent samples t-test was used to compare the numerical variables between groups and see if the assumptions were met. If not, a Mann-Whitney U test was used, and a one-way analysis of variance (ANOVA) was used to compare more than two groups. A p value of $<0.05$ was considered statistically significant.

\section{RESULTS}

Demographic characteristics did not differ between patients with heart failure and controls (Table 1). Heart failure patients have lower ejection fraction $(32.7 \pm 5.7$ vs $66.2 \pm 4.2, \mathrm{p}<0.001)$. A total of $157 \mathrm{HF}$ patients (94 (\%60) female, mean age: 74.3 \pm 6.7) grouped according to NYHA functional class. NYHA functional dispersion were as following: Fifty-four patients in function class I, 67 in class II, 21 in class III and 15 in class IV.

Table 1. Clinical laboratory and echocardiography findings of the study population

\begin{tabular}{|c|c|c|c|}
\hline & Heart Failure (n=157) & Control $(n=155)$ & P value \\
\hline Age (years) & $74.3 \pm 6.7$ & $72.6 \pm 5.4$ & NS \\
\hline Gender $(\mathrm{M} / \mathrm{F})$ & $94 / 63$ & $99 / 56$ & NS \\
\hline Smokers $(\mathrm{N}(\%))$ & $42(26.7 \%)$ & $48(30.9 \%)$ & NS \\
\hline Systolic BP (mmHg) & $125(95-140)$ & $123(90-140)$ & NS \\
\hline Diastolic BP (mmHg) & $78(60-85)$ & $74(50-90)$ & NS \\
\hline Height $(\mathrm{cm})$ & $163.4 \pm 8.5$ & $165.5 \pm 8.7$ & NS \\
\hline Body weight $(\mathrm{kg})$ & $75.5 \pm 13.7$ & $73.3 \pm 11.5$ & NS \\
\hline BMI $\left(\mathrm{kg} / \mathrm{m}^{2}\right)$ & $28.1 \pm 3.9$ & $26.8 \pm 4.1$ & 0.015 \\
\hline FPG (mg/dl) & $95(76-110)$ & $91(67-110)$ & 0. \\
\hline Creatinine (mg/dl) & $1.0(0.6-2.4)$ & $1.0(0.5-4.6)$ & NS \\
\hline Total cholesterol (mg/dl) & $205.5 \pm 18.9$ & $199.7 \pm 17.9$ & NS \\
\hline LDL-Cholesterol (mg/dl) & $123.2 \pm 43.5$ & $126.4 \pm 31.8$ & NS \\
\hline HDL-Cholesterol (mg/dl) & $45.2 \pm 12.0$ & $47.2 \pm 11.9$ & NS \\
\hline Triglyceride $(\mathrm{mg} / \mathrm{dl})$ & $156(31-432)$ & $148(31-323)$ & NS \\
\hline ALT (U/L) & $18(5-45)$ & $16(2-41)$ & NS \\
\hline AST (U/L) & $21(13-45)$ & $21(9-40)$ & NS \\
\hline ALP (U/L) & $78.5 \pm 21.5$ & $76.8 \pm 20.5$ & NS \\
\hline GGT (U/L) & $24(12-43)$ & $25(7-51)$ & NS \\
\hline Bone Alkaline Phosphatase (U/l) & $18.7(2.9-201)$ & $10.3(2.0-41.1)$ & $<0.001$ \\
\hline 25 hydroxyvitamin-D (ng/ml) & $15.1 \pm 10.2$ & $29.1 \pm 20.4$ & $<0.001$ \\
\hline LVEDD & $6.4 \pm 0.5$ & $4.6 \pm 0.5$ & $<0.001$ \\
\hline LVESD & $5.2 \pm 0.6$ & $2.9 \pm 0.4$ & $<0.001$ \\
\hline LVEF & $32.7 \pm 5.7$ & $66.2 \pm 4.2$ & $<0.001$ \\
\hline
\end{tabular}

LVEDD: left ventricle end diastolic diameter; LVESD: left ventricle end systolic diameter; LVEF: left ventricle ejection fraction

The prevalence of osteoporosis was significantly more frequent in patients with heart failure compared to control subjects at the total hip, femoral neck and lumbar spine (Table 2). Among the 157 patients, 45 (29\%) had normal BMD, 14 (9\%) had osteopenia, and 98 (62\%) had osteoporosis. In 155 control subjects, 68 (44\%) had normal BMD, 12 (8\%) had osteopenia, and 75
(46\%) had osteoporosis $(\mathrm{P}=0.019)$. Sixteen subjects $(10.2 \%)$ in heart failure group and 6 subjects $(3.9 \%)$ in controls had hip fracture $(\mathrm{p}=0.029)$. There was no lumbar fracture in the study population.

Bone specific alkaline phosphatase levels were significantly higher in patients with heart failure compared to the control group (18.7 (2.9$201)$ vs. 10.3 (2.0-41.1), $\mathrm{p}<0.001)$. Level of 25 - 
Table 2. BMD values in patients with heart failure versus control subjects at each main skeletal sites

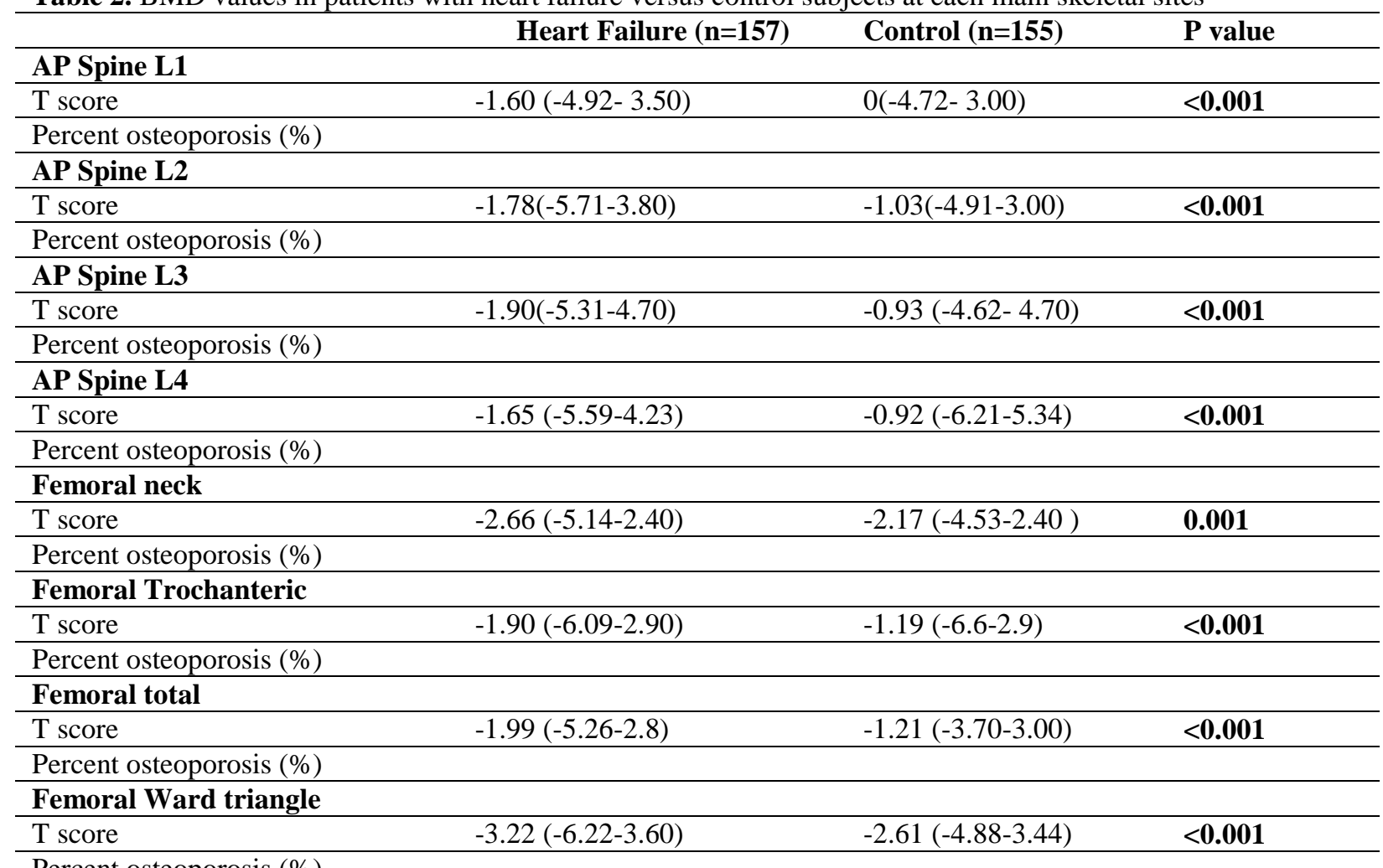

Percent osteoporosis (\%)

hydroxyvitamin D was significantly lower in heart failure than in controls $(15.1 \pm 10.2$ vs. $29.1 \pm 20.4$ $\mathrm{ng} / \mathrm{ml} ; \mathrm{p}<0.001)$. Another marker of bone formation, serum osteocalcin, was not different between groups.

\section{DISCUSSION}

This study concluded that heart failure was correlated with a significant worsening of femoral and vertebral bone mineral density parameters. A significant association was identified between LVEF and these parameters. Compared to the control group, we also found that there were more frequent hip fractures in patients with heart failure.

Previous studies attributed low bone mass to increased cardiovascular conditions. There are several studies evaluating the epidemiology of hip fractures in heart failure. This study is a significant contribution to studies evaluating the epidemiology of hip fractures in heart failure. Van Diepen et al reported a 6-fold increased risk of hip fractures following a diagnosis of heart failure compared with patients having a cardiovascular disease without heart failure in the first year (8). Our study also demonstrated 3-fold increased prevalence of hip fracture in heart failure $(3,9$ vs $10.2 \%, \mathrm{p}=$ 0.029). Our study aimed to assess both BMD and hip fracture data in heart failure.

Carbone et al demonstrated that patients with heart failure are at high risk for fractures of the hip. Moreover, they showed that hip fractures are a substantial contributor to mortality in men and women with heart failure (9). The result of our study is concordant to their findings. As superiority to other similar studies, we analyzed $25-\mathrm{OH}$ vitamin D levels and found that they are significantly lower in heart failure patients.

There can be some explanations for association between BMD and cardiovascular conditions. The exact mechanism of this association isn't totally understood yet. Theoretically it can be attributed to the common risk factors that influence both heart failure and bone metabolism. Commonly known risk factors for cardiovascular disease include male sex, menopause and advanced age. Other risk factors for cardiovascular disease such as hypertension, oxidative stress, diabetes, dyslipidemia, and inflammation have also been related with increased risk of low BMD. Other possible explanations are inflammation, low vitamin D level and nitric oxide (10). Inflammation highly affects the process of OP as well as the condition of heart failure. Nitric oxide, which is a known mediator in pathophysiology of heart failure, may also have osteoblastic activity. It also effects bone turnover (11-13).

Study limitations The study is retrospective which is it's the main limitation. This study was planned as a cross-sectional manner, so causality could not be determined. Further studies with a prospective follow up including mortality and hip fracture analyses are needed.

Conclusion: Patients with heart failure have a lower bone mineral density, low vitamin D level and an increased rate of hip fractures. Shared risk factors and pathogenic mechanisms affect these findings. Further prospective studies should be 
performed for evaluating the role of heart failure in osteoporotic hip fractures.
Conflict of interest: None declared. Peer-review: Externally peer-reviewed.

\section{REFERENCES}

1. Newman AB, Gottdiener JS, Mcburnie MA, Hirsch CH, Kop WJ, Tracy R, et al. Associations of subclinical cardiovascular disease with frailty. J GerontolA Biol Sci Med Sci. 2001;56:M158-66.

2. Walston J, McBurnie MA, Newman A, Tracy RP, Kop WJ, Hirsch CH, et al. Frailty and activation of the inflammation and coagulation systems with and without clinical comorbidities: results from the Cardiovascular Health Study. Arch Intern Med. 2002;162:2333-41.

3. Kenny AM, Waynik IY, Smith J, Fortinsky R, Kleppinger A, McGee D. Association between level of frailty and bone mineral density in community-dwelling men. J Clin Densitom. 2006;9:309-14.

4. Cankurtaran M, Yavuz BB, Halil M, Dagli N, Ariogul S. General characteristics, clinical features and related factors of osteoporosis in a group of elderly Turkish men. Aging Clin Exp Res. 2005; 17:108-15

5. Wiktorowicz ME, Goeree R, Papaioannou A, Adachi JD, Papadimitropoulos E. Economic implications of hip fracture: health service use, institutional care and cost in Canada. Osteoporos Int. 2001;12:271-278.

6. Yesil Y, Ulger Z, Halil M, Halaclı B, Yavuz BB, Yesil NK, et al. Coexistence of osteoporosis (OP) and coronary artery disease (CAD) in the elderly: It is not just a by chance event. Arch GerontolGeriatr. 2012;54:473-6.

7. Genant HK, Cooper C, Poor G, Reid I, Ehrlich G, Kanis J, et al. Interim report and recommendations of the World Health Organization Task-Force for Osteoporosis. Osteoporos Int. 1999;10:259-64.

8. van Diepen S, Majumdar SR, Bakal JA, McAlister FA, Ezekowitz JA. Heart failure is a risk factor for orthopedic fracture: a population-based analysis of 16,294 patients. Circulation. 2008;118:1946-52

9. Carbone L, Buzková P, Fink HA, Lee JS, Chen Z, Ahmed A, et al. Hip fractures and heart failure: findings from the Cardiovascular Health Study. Eur Heart J. 2010;31:77-84.

10. Cetin M, Kozdağ G, Ural D, Kahraman G, Yılmaz I, Akay Y, et al. Could decreased vitamin D levels be related with impaired cardiac autonomic functions in patients with chronicheart failure: an observational study. Anadolu Kardiyol Derg. 2014;14:434-41.

11. Anagnostis P, Karagiannis A, Kakafika AI, Tziomalos K, Athyros VG, Mikhailidis DP. therosclerosis and osteoporosis: age-dependent degenerative processes or related entities? Osteoporos Int. 2009;20:197-207.

12. Eastell R, Newman C, Crossman DC. Cardiovascular disease and bone. Arch BiochemBiophys. 2010;503:78-83.

13. Manolagas SC. From estrogen-centric to aging and oxidative stress: a revised perspective of the pathogenesis of osteoporosis. Endocr Rev. 2010;31:266-300. 